\title{
An Empirical Investigation on Credit Card Repayment Pattern of Academicians in Malaysia
}

Kuah Yoke Chin

Faculty of Business and Finance, Universiti Tunku Abdul Rahman, Malaysia

Wei Chooi Yi

Faculty of Business and Finance, Universiti Tunku Abdul Rahman, Malaysia

Chin Lai Kwan

Faculty of Business and Finance, Universiti Tunku Abdul Rahman, Malaysia

Chia Mei Si

Faculty of Business and Finance, Universiti Tunku Abdul Rahman, Malaysia

*Corresponding author: kuahyc@utar.edu.my

\section{A R T I C L E I N F O}

Article history:

Received 16 May 2018

Revised 21 June 2018

Accepted 27 June 2018

Keywords:

Personal attitude, Spending pattern,

Repayment pattern; Gender, parenthood

JEL Code: D14

\section{A B S T R A C T}

The credit card market has witnessed tremendous growth resulting from a paradigm shift in technology. The genuine usage of credit cards as a form of convenience has diverged to overspending, irresponsibility, revolving liability and bankruptcy. This implies that possession of credit cards has brought about a change in users' repayment behavior. Thus, this study aims to determine academicians' credit card repayment pattern in a private tertiary institution in Malaysia. The dependent variable is the repayment pattern and the independent variables that serve as the attributes include personal attitude and spending pattern, while, gender and parenthood serve as the moderating variables. Findings revealed that personal attitude and spending pattern were important attributes in determining the repayment pattern among the academicians. Gender 
and parenthood were found to play a moderating role in the repayment pattern. Findings from this study is expected to facilitate the government and credit card companies to work towards nurturing a financially healthier and informed society, and also to reach out positively to the younger generations through the influence of the academicians

\section{Introduction}

The usage of credit card as a medium of payment has evolved tremendously since their introduction in the United States in the early 20th century (Ahmed, Ismail, Sohail, Tabsh, \& Alias, 2010). Credit cards provide an easy and convenient mode of payment to users. A credit card user is only required to present a plastic card loaded with a pre-approved amount to merchants upon transaction at the checkout counter to enjoy the benefits of goods and services. No cash payment is required at the point of purchase. The demand for credit cards accelerated when users began to realize such benefits credit cards offered. Huebner, Fuchs and Ilic (2018) supported the credit card payment mechanism as a direct result of the development of a cashless society.

The issuance of credit card was primarily intended to benefit both the merchant and consumer markets. Merchants leverage on credit card usage to stimulate sales and to provide a facility to complete purchases, while consumers leverage on credit card usage to expand their purchasing power. The credit card issuer is practically advancing cash to the user upon transacting and the user is only required to settle the payment at a later date. Such financing facility in the form of unsecured loans provided by the issuer is far easier to obtain by users compared to other financing means that require a lengthy and complicated process (Elangkovan \& Ahmed, 2013).

Despite the convenience payment and financing flexibility that credit cards offer, users tend to misuse the cards. At the time of purchase, they often or are likely to underestimate the price of goods and portray a lack of awareness of the amount that have been charged to their cards, leading to overspending. At the time of repayment, users tend to pay only the minimum required amount, gradually accumulating a larger credit balance in their credit cards.

The consequence of credit card usage in Malaysia is apparent. According to Bank Negara Malaysia (BNM) (2016), the total outstanding balances due from cardholders in Malaysia amounted to RM35.77 million as of June 2016. However, 
total purchases for the period was only RM10.26 million, representing $28.7 \%$ of the total outstanding balances. This meant that the remaining $71.3 \%$ were accumulated credit card debts from previous periods. In addition, a depressing fact was revealed that the total amount of bank loan applications by individuals for the purpose of credit card repayments had increased by $56.8 \%$ over a one-year period ending June 2016 from RM26.657 million to RM41.785 million (BNM, 2016). Such increase signaled that credit card debts are rising. In contrast, users' ability to repay credit card debts are thinning, leading them to seek bank loans as an alternative to resolve their debts. In addition, non-performing loans attributed to credit cards payments in Malaysia are high. Lydia (2017) in "The Malaysian Reserve" reported that the non-performing loan (NPLs) related to purchases via plastic cards was at RM473.3 million as at end of May 2017. Such an amount has raised concerns on credit card traps.

Ahmed et al. (2010) stated that the easy availability of financing by credit cards has led to many adverse consequences such as compulsive spending and excessive debt. This is supported by Omar, Rahim, Wel, and Alam (2014) who added that users regarded the plastic card as a booster to self-esteem and tended to use it to satisfy their craving for material things, which resulted in financial distress and bankruptcy. The original intent of the credit card as a form of "convenience payment" has alluded to mean "overspending", "irresponsibility", "revolving liability" and "bankruptcy". This indicated that the possession of credit cards has brought about a change in users' repayment pattern.

Previous empirical studies on credit cards were predominantly focused on college students and working adults. Limited studies were available on academicians. Cebeci and Sanli (2016) conducted a study concerning academicians' attitude towards credit card usage on 158 academicians in a university in Turkey in 2015. The study found that the trust on credit card had a significant and positive impact on credit card usage among the academicians, as the academicians did not have to adjust their expenses according to their budget when they used credit cards. In addition, the study also found that the usage of credit cards did not lead to overspending. The trust on credit card usage also did not cause irregular spending and excessive borrowing among the academicians.

However, outcomes from the study by Cebeci and Sanli (2016) are unable to be generalized to other countries due to differences in legal, cultural, geographical and socio-economic structures between countries, industries and markets. In addition, the study focused on academicians' credit card usage as their dependent variable, and not their repayment behavior.

Most of the past studies had been conducted on credit card usage behaviors in Malaysia (Ramayah, Nasser, Aizzat, \& Lim, 2002; Ahmed et al., 2010; Nga, Yong \& Sellappan, 2011; Jusoh \& Lin, 2012; Rasiah \& Masuod, 2013). Hence, this study attempts to fill research gaps by focusing on credit card repayment behaviors, with emphasis on academicians in a private tertiary institution. 
Attitude and leadership skills of academicians have a direct influence on the younger generation. In this respect, an academician is encouraged to portray a positive attitude and leadership skills in their coaching. According to Nurul Hudani, Marof, and Noor Hisham (2013), self-management and social awareness are closely associated with the development of a positive attitude and leadership traits. This implied that academicians should possess a high level of self-management and social awareness. Such positive attributes contribute to academicians' ability to exercise discipline in their actions and a heightened awareness on the consequences of their actions.

This study aims to provide evidence to explain the credit card repayment pattern among academicians in a private tertiary institution in Malaysia. Six research objectives are addressed in this study to investigate the relationship between personal attitude and spending pattern with the credit card repayment pattern of academicians. Next, this study will investigate the relationship between the spending pattern and personal attitude of academicians with their credit card repayment pattern based on their gender and parenthood.

\section{Literature Review}

The literature review in this study is divided into three parts. Firstly, credit card repayment pattern as the dependent variable will be discussed. McHugh and Ranyard (2012) indicated that repayment pattern varies among individuals based on income level, and attitude toward credit and debt. In addition, people who are future oriented will be motivated to maximize repayments in order to ameliorate the negative impact on credit decision (Webley \& Nyhus, 2001). Some tend to repay significantly more when they comprehend the long-term consequences (McHugh \& Ranyard, 2012). The characteristics of people who are willing to repay a higher amount are those that place value on achievement, self-direction, have a clear interpretation of borrowing and uses credit appropriately (Wang, Lu, \& Malhotra, 2011). Leow and Crook (2014) found that the self-employed and unemployed are at a higher risk of repayment delinquency compared to those who are employed. However, the ability to recover for employees may be lesser once they enter into repayment delinquency. Thus, those who are frequently delinquent in repayments are more likely to go into delinquency again but not defaulting. This is due to the stable income that the employees enjoy while the self-employed and unemployed do not. However, the self-employed and unemployed are better in balancing their accounts and more able to stay out of defaulting.

In 2017, credit card billings amounted to RM180 billion (Bernama, 2017). According to the then Deputy Finance Minister of Malaysia, an average of $43.6 \%$ of total cardholders settled their credit card debts completely between January and June 2017 . However, there was at least $5 \%$ of outstanding balance while $12.8 \%$ 
did not even settle the minimum payment before or on the due date (Tasnim, 2017). According to Stewart (2009) and Navarro-Martinez, Salisbury, Lemon, Stewart, Matthews and Harris (2011), the presence of minimum repayment information on a credit card statement reduces the consumer's partial repayment decision. Wang et al. (2011) defined revolving credit as three particular behaviors - repaying over the course of time, paying equal to or greater than the minimum required repayment and using up a revolving credit limit. Furthermore, Furnham and Boo (2011) explained that the minimum repayment amount represents a number that can sway judgments and decisions for anchoring effect which influences the consumer's repayment decision.

Secondly, personal attitude towards credit card spending and repayment will be discussed. The cashless payment mechanism has changed attitude toward the usage of credit cards throughout the world. The large and growing educated population in Malaysia has influenced the acceptance of credit cards or plastic money. In 2017, Malaysia hit 3.6 million main credit card holders with a RM36.9 billion outstanding balance (Tasnim, 2017). Initially, credit card usage was linked with luxury spending. However, it has now transformed to support daily expenses. Convenience and the carry forward on payment have changed the consumer's attitude toward credit card usage (Ramayah et al., 2002). Chan (1997) defined an active credit card user as an individual who spends with credit card more than 10 times per month.

According to Chien and Devaney (2001), the more favorable an individual's attitude toward credit spending, the higher the outstanding debt. Consumer attitude toward credit card usage contribute to the increasing household outstanding debt (Kish, 2006). Lachance (2012) showed a positive relationship between attitude toward credit on education, the number of credit cards owned and knowledge of credit. Kidwell and Turrisi (2000) and Hayhoe, Leach, Turner, Bruin and Lawrence (2000) found that the cognitive variable and affective credit attitude influenced the acquiring of credit card and its usage. People are willing to spend more when they pay with credit card, contributing to compulsive spending along with shorter decision-making time for item purchase (Feinberg, 1986; Shimp \& Moody, 2000; Soman, 2001; Awanis \& Chi Cui, 2014). This is because cash payments represent immediate parting of money, which create the "pain of paying" and thus stimulates self-control on spending (Chatterjee \& Rose, 2011; Raghubir \& Srivastava, 2008).

Overvaluation of available income and undervaluation of past expenses lead to spending a greater amount than the credit limit allows (Soman \& Cheema, 2002). In addition, low self-regulatory capabilities result in credit card misuse and indebtedness (Chatterjee \& Rose, 2011). In a study by Wong and Lynn (2017), credit card payment method conjures up easy money which causes a momentary underestimated effort in income gaining thus lowering a perceived value of money. As a result, consumers are encouraged to spend easily as they are inspired by the "easy-money effect". 
Based on the above arguments and past evidences, the first hypothesis of this study is as follows:

Hypothesis 1: There is a significant relationship between personal attitude and academicians' credit card repayment pattern.

Thirdly, spending pattern and credit card repayment pattern will be discussed. Related literature has acknowledged the effects of credit card spending on a nation's socio-economy, personal finance and psychological health and well-being (Chien \& Devaney, 2001; Brown, Taylor, \& Price, 2005). The cost associated with delinquency in payments can be far-reaching. The "buy now, pay later" stimulus that credit card offers has been attributed to massive credit build-up, resulting in card owners falling into deepening debt traps (Livingstone \& Lunt, 1992; Ausubel, 1997; Yoo, 1998; Silva \& Draut, 2004; Stavins, 2006). Economists and financial experts worldwide have signaled the alarming credit card debt traps as an onset of debt crisis at national level (Chong, 2017; Surane, 2017; Bresiger, 2018).

The multifunctional aspects of credit cards with their ability to purchase beyond affordability, to maintain a degree of anonymity in certain purchases and leverage on revolving provisions have led to an increase in credit card spending (Klein, 1999). Prelec and Simester (2001) highlighted that the willingness-topay with credit card increases when consumers are instructed to use credit card rather than cash. In addition, Feinberg (1986) posited that the consumer tends to spend a higher amount on a credit card purchase than a cash purchase for an identical purchase situation. Soman (2001) concurred that credit card spending induces further purchases, as his study showed that consumers who made past payments with credit cards were more likely to spend on additional discretionary purchases. Soll, Keeney and Larrick (2013) have also highlighted that consumers portrayed poorer recollection of their previous spending. More significantly, consumers experienced reduced levels of psychic pain when spending with credit cards in comparison with cash spending. These implied that credit card spending increased the likelihood to purchase, thus incurring a higher payable amount. Thus the "buy more now, pay later" attitude is expected to lead to a behavioral change in debt repayment pattern among cardholders.

According to Bertaut and Haliassos (date) and Reiter (2009), the majority of US credit card holders revolve their credit card balance, even though they have substantial liquid and retirement assets. Both the studies also suggest that credit card revolvers choose not to be debt-free for consumption smoothing, high switching cost from credit card usage to debit card usage or habitual reasons. Kim and DeVaney (2001) examined the factors affecting outstanding credit card balances among debt revolvers in US. Their findings proved that spending attitude (in particular on essentials and elective purchases) is significantly related to the likelihood of revolving credit card balances. In addition, increment in the 
spending power of an individual, leveraging on higher credit limits available or a higher number of credit card ownership, are positively related to revolving balances. Interestingly, they found that among the revolving credit card owners, education was positively related to the amount of outstanding credit card balances. On the contrary, Sprenger and Stavins (2008) showed that higher credit card spending had reduced the likelihood of cardholders revolving their balances. His study proved that revolvers do not only adopt, but also used debit more frequently in order to control their spending than convenience users. Tan, Yen and Loke (2011) in their study on credit card revolvers in Malaysia proved that consumer's general financial/credit consumption tendencies are relevant in explaining both the probability and level of card debt. The study revealed that high financial commitments, high current account balances coupled with a bad debt history, will limit credit card spending ability, hence, leading to a more prudent repayment pattern.

Designated professions such as academicians in universities have greater access to revolving credit facilities as credit limits are normally set by income levels compared to undesignated professions which have very low or limited access to financing options (Dewri, Islam \& Saha, 2016). The influence of the plastic card has, not only, been associated to changes in consumer spending patterns but also associated to changes in debt repayment patterns (Soll et al., 2013; Soman, 2001; Hamilton, \& Khan, 2001; Zhao, Zhao, \& Song, 2009). Most of the literature examined looked at the influence of credit card usage in spending and/or repayment patterns. There are limited empirical findings on how credit card spending influences the repayment pattern of cardholders. This study aims to close the gap in literature. The spending pattern of academicians in a university would be analyzed in this study based on the above arguments and past evidences. Thus, the second hypothesis of this study is as follows:

Hypothesis 2: There is a significant relationship between spending pattern and academicians'credit card repayment pattern.

Apart from this, numerous studies have been undertaken in the past to differentiate usage behavior based on gender. Mottola (2013) proved that more women were engaged in costly credit card behaviors than men in the US. The study via questionnaires showed that women, in comparison to men, were more likely to rollover credit card balances, more likely to pay the minimum amount on their cards, and more likely to be charged a late fee. In addition, women were less likely to compare rates when they signed up for credit cards. Elangkovan and Ahmed (2013) proved that women tend to overspend on unexpected and unnecessary expenses compared to men in Malaysia. Yet, this finding contradicted with the outcome by Hussin, Kassim, and Jamal (2013) whose findings revealed that there were no significant differences between male and female consumers with regards to credit card spending and repayment in Klang, Malaysia. 
However, Cankaya, Ucal and O’Neil (2011) found that women in Turkey understood better compared to men on the consequences of their credit card spending since they were keen to make full and on time payment rather than servicing minimum payment. Turkish women spent mainly on food, clothing, cosmetics and household goods using credit cards. Similar results were obtained from Limbu, Huhmann and Xu (2012) who reported that women were far better than men in managing monthly outstanding balances, implying that women were more cautious in their credit card usage and finances. They reasoned that women had a lower tendency to take risks, thus they disassociated themselves from excessive credit card debts.

Similar results were obtained from previous studies by Themba and Tumedi (2012) who revealed that the youth and females had a negative attitude towards debt. This gender based attitude differed due to differences in culture, religious beliefs, earning capacity and credit availability (Dewri et al., 2016). Thus, understanding gender differences in credit card repayment has significant implications. Therefore, this study has included gender as a moderating variable to differentiate the relationship of personal attitude and spending pattern on credit card repayment pattern between male and female academicians at Universiti Tunku Abdul Rahman (UTAR), Kampar campus. Thus, the third and fourth hypothesis of this study is as follows:

Hypothesis 3: There are significant differences between personal attitude and credit card repayment pattern based on gender.

Hypothesis 4: There are significant differences between spending pattern and credit card repayment pattern based on gender.

The degree of family commitment of credit card holders in terms of child support, which is represented by parenthood in this study, is expected to influence credit card spending and repayment pattern. Kinsey (1981) found that two-people households had more credit cards than single-person households, as two-people households tend to have higher expenses in their daily lives. Besides that, Godwin (1998) has proven that the larger the household size, the larger the household debt. Chien and Devaney (2001) also found that a larger-sized household was more likely to have a favourable attitude towards credit card usage and to have a higher outstanding credit card balance. Similarly, Bertaut and Haliassos (2001) found that households with more children were more likely to have higher levels of usage leading to higher credit card debt. Past studies have been conducted for over a decade and it has proven that more children meant higher daily household expenses. In this study, the researcher will revisit past studies by Kinsey (1981), Chien and Devaney (2001), Godwin (1998) and Bertaut and Haliassos (2001) taking into consideration parenthood as the moderating 
variable to investigate the attributes that influence credit card repayment pattern. Thus, the fifth and sixth hypothesis of this study is as follows:

Hypothesis 5: There are significant differences between personal attitude and credit card repayment pattern based on parenthood.

Hypothesis 6: There are significant differences between spending pattern and credit card repayment pattern based on parenthood.

The Theory of Planned Behavior (TPB) is a theory to describe the relationship between personal attitude and spending pattern with the credit card repayment pattern of academicians. This Theory of Planned Behavior was developed by Icek Ajzen in 1991. This theory was developed to predict a person's behavior through their intentions to improve on the predictive power of the Theory of Reasoned Action (TRA) by including perceived behavior control. Previous studies such as by Amin (2013) has extended the theory of TRA to examine the acceptance factor of attitude, subjective norm and perceived financial cost within the context of Islamic credit cards. Amin (2012) has employed TRA in his study to examine factor(s) towards Islamic credit card usage intention.

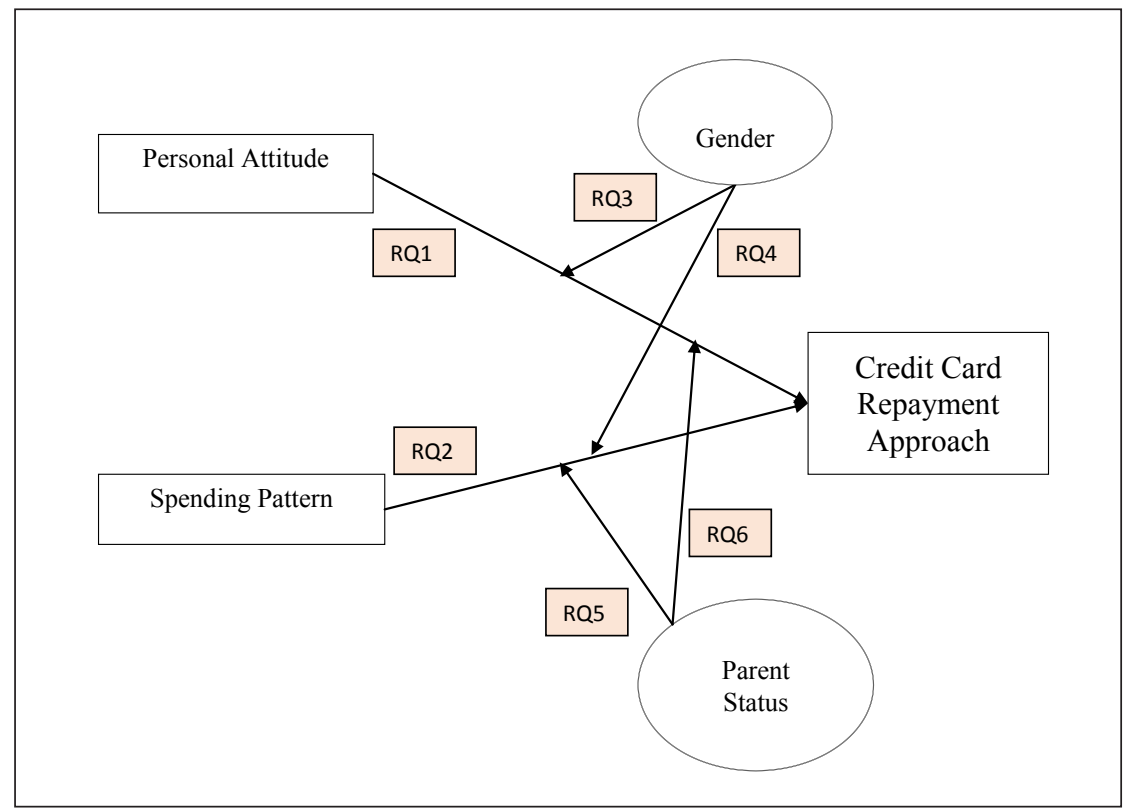

Figure 1. Conceptual Framework

As in the TPB theory, human behavior is influenced by behavioral beliefs, normative beliefs and control beliefs. The behavioral beliefs create a favorable 
or unfavorable attitude towards the behavior (ATB). On the other hand, the normative beliefs give rise to subjective norms (SN), while a rise in perceived behavioral control (PBC) is always a result of control beliefs (Ajzen, 2006). This theory applies to studies on relations among beliefs, attitudes, behavioral intentions and behavior in various fields such as advertising, public relations, advertising campaigns and healthcare. Previous studies such as by Chudry, Foxall and Pallister (2011) examined attitudes toward borrowing from an education loan institution relative to the credit card institution by adapting the TPB in United Kingdom. Their findings revealed that attitude positively affected perceived behavioral control. Similar studies which applied the theory of TPB was in a study by Kennedy and Wated (2011) which indicated that attitude positively influenced credit card usage intention. Thus, in this study, personal attitude and spending pattern served as the independent variables, moderated by gender and parenthood to examine credit card repayment pattern among academicians in a private tertiary institution. The conceptual framework is shown in Figure 1 as follows:

\section{Methodology}

This exploratory study was conducted at Universiti Tunku Abdul Rahman (UTAR), Kampar Campus, Perak, Malaysia. The main purpose of this study was to determine the attributes of UTAR academicians in repaying their credit card spending. The population in this study consisted of 590 academicians from six different faculties, namely the Faculty of Engineering and Green Technology (FEGT), Faculty of Information and Communication Technology (FICT), Faculty of Arts and Social Science (FAS), Faculty of Science (FS), Faculty of Business and Finance (FBF) and Institute of Chinese Studies (ICS). Stratified sampling technique was applied to determine the ratio of sample size to be obtained in each faculty. The relevant ratio via stratified sampling technique was applied to obtain data from each faculty in order to avoid response bias in this study. Based on Table 1, the approximate sample size would be 234 samples for a population of 600 academicians (Krejcie \& Morgan, 1970). In addition, Sekaran and Bougie (2009) suggested that a sample size larger than 30 units but less than 500 units was appropriate for most research. Thus, to ensure that the sample size was large enough, 250 questionnaires were administered to the academic staff across the faculties according to the ratio of sample obtained via the stratified sampling technique. 
Table 1. Determining Sample Size of a Known Population

\begin{tabular}{ll}
\hline Population & Sample size \\
\hline 500 & 217 \\
550 & 226 \\
600 & 234 \\
650 & 242 \\
700 & 248 \\
\hline
\end{tabular}

Source. Krejcie and Morgan (1970)

\section{Results}

All collected data were analyzed using Statistical Package for the Social Sciences (SPSS) version 23 and Partial Least Squares - Structural Equation Model (PLSSEM). The structural model was analyzed using SmartPLS 3.2 to perform PLSSEM to test the hypothesized relationships among the constructs in the model depicted in Figure 2.

PLS-SEM is taken as the rigorous and most appropriate method to test the hypothesis in this study because it can handle samples with normality issues. In fact, PLS-SEM is a non-parametric approach, thus, distributional assumption is not required. In addition, PLS-SEM is able to achieve high levels of statistical power with small sample sizes (Hair, Black, Babin \& Anderson, 2010).

As shown in Table 2, the highest number of respondents was from the Faculty of Business and Finance (FBF) (41.9\%). There were 127 males (55.5\%) and 102 females (44.5\%) in the sample. A majority of the respondents spent around RM501 to RM1000 on goods and services on a monthly basis using credit card.

Table 2. Demographic Profile of Respondents

\begin{tabular}{cccc}
\hline & & Frequency & Percentage (\%) \\
\hline \multirow{3}{*}{ Gender } & Male & 127 & 55.5 \\
& Female & 102 & 44.5 \\
\multirow{3}{*}{ Faculty } & & & \\
& FEGT & 30 & 13.1 \\
& FICT & 15 & 6.6 \\
& FAS & 35 & 15.3 \\
\hline & & & (continued)
\end{tabular}




\begin{tabular}{cccc}
\hline & & Frequency & Percentage (\%) \\
\hline & FS & 44 & 19.2 \\
& FBF & 96 & 41.9 \\
& ICS & 9 & 3.9 \\
Average usage via & RM100 - RM500 & 71 & 31.1 \\
credit card (monthly) & & & \\
& RM501 - RM1000 & 89 & 38.9 \\
& RM1001 - RM1500 & 30 & 13.1 \\
Do you have & & & 17.0 \\
children? & $>$ RM1500 & 39 & 53.4 \\
& Yes & 117 & 46.6 \\
\hline
\end{tabular}

To ensure the credibility of the questionnaire and the results, the designed instruments went through the process of validity and reliability check. First, convergent validity was tested which is the degree to which multiple items that are used to measure the same concept are in agreement. As suggested by Hair et al. (2010), factor loading, composite reliability and average variance extracted were the indicators used to access convergent validity.

The loading for all items exceeded the recommended value of 0.6 (Chin, Gopal \& Salisbury, 1997). As shown in Table 3, the composite reliability values depicted the degree to which the construct indicator showed that the latent construct ranged from 0.829 to 0.889 , which was higher than the recommended value of 0.7 (Hair et al., 2010). The average variance extracted, which reflected the overall amount of variance in the indicators accounted for by the latent constructs, were in the range of 0.533 to 0.652 , which met the recommended value of 0.5 (Hair et al., 2010).

Table 3. Factor Loading and Reliability

\begin{tabular}{lcccc}
\hline & Loading & $\begin{array}{c}\text { Composite } \\
\text { Reliability }\end{array}$ & $\begin{array}{c}\text { Average Variance } \\
\text { Extracted }\end{array}$ & Cronbach's Alpha \\
\hline B4 & 0.630 & 0.829 & 0.555 & 0.721 \\
B5 & 0.852 & & & \\
B6 & 0.856 & & & \\
B7 & 0.604 & & 0.652 & 0.825 \\
D1 & 0.845 & 0.882 & & \\
D2 & 0.779 & & & \\
\hline
\end{tabular}




\begin{tabular}{lcccc}
\hline & Loading & $\begin{array}{c}\text { Composite } \\
\text { Reliability }\end{array}$ & $\begin{array}{c}\text { Average Variance } \\
\text { Extracted }\end{array}$ & Cronbach's Alpha \\
\hline D3 & 0.750 & & & \\
D4 & 0.850 & & & \\
E1 & 0.665 & 0.889 & 0.533 & 0.854 \\
E4 & 0.721 & & \\
E5 & 0.769 & & \\
E6 & 0.726 & & \\
E7 & 0.707 & & \\
E8 & 0.724 & & \\
E9 & 0.795 & & \\
\hline
\end{tabular}

Discriminant validity is the extent to which the measures do not reflect other variables and it is indicated by low correlations between variables by examining the comparison between average variance extracted (AVE). Based on the formula by Fornell and Larker (1981), it requires that the square root for each construct (AVE) be higher than all its correlation with other constructs. As shown in Table 4 , the squared correlations for each construct were less than the square root of the average variance extracted, so it can be inferred that the constructs have a good level of validity.

Table 4. Inter-construct Correlation

\begin{tabular}{lccc}
\hline & Personal attitude & Repayment pattern & Spending pattern \\
\hline Personal attitude & 0.745 & & \\
Repayment pattern & 0.600 & 0.730 & \\
Spending pattern & 0.505 & 0.730 & 0.807 \\
\hline
\end{tabular}

Once the reliability and the validity of the measures are assured, path coefficients can be reported based on the results of a PLS structural model. Table 5 shows the significance of the path coefficients. The t-value which can be compared with critical value forms the standard normal distribution to decide whether the coefficients are significantly different from zero. For instance, the critical value for a significance level of 5 percent, the probability of error is 1.96 (twotailed test). In this study, the results showed that personal attitude and spending pattern were significant attributes of the credit card repayment pattern of academicians. 


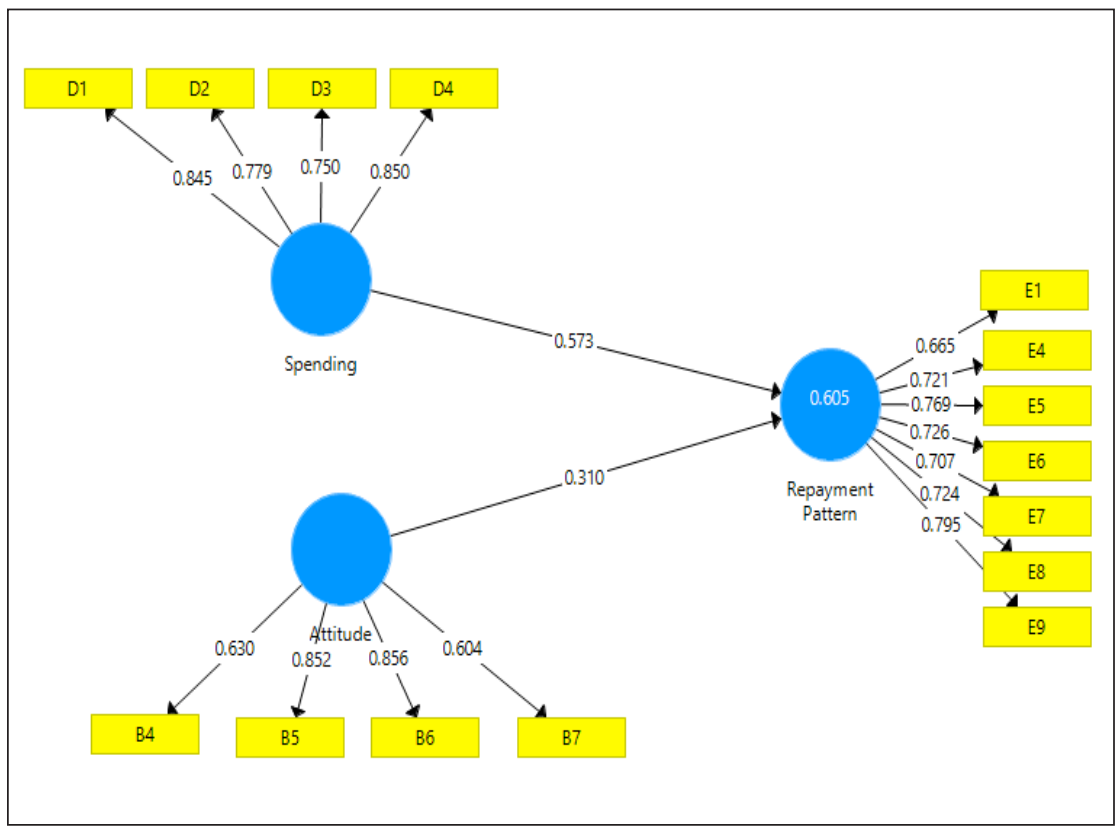

Figure 2. Bootstrapping Result from PLS-SEM

Table 5. Summary of the Structural Model

\begin{tabular}{lcccc}
\hline Description & Hypothesis & $\begin{array}{c}\text { Path } \\
\text { coefficient }\end{array}$ & t-value & Results \\
\hline $\begin{array}{l}\text { Personal Attitude -> } \\
\text { Repayment pattern }\end{array}$ & H1 & 0.310 & $3.884^{* * * *}$ & Supported \\
$\begin{array}{l}\text { Spending Pattern-> } \\
\text { Repayment pattern }\end{array}$ & H2 & 0.573 & $8.967^{* * *}$ & Supported \\
\hline
\end{tabular}

Note. All p-values are two-tailed, * significant at $0.05, * * *$ significant at 0.001 .

Besides this, a non-parametric multi-group analysis (PLS-MGA) method were conducted to see whether there was a significant difference in credit card repayment pattern between female and male academicians. A difference is significant if the p-value is smaller than 0.05 . As seen from Table 6 , there were significant differences across the male and female groups at 0.05 significant level for personal attitude and spending pattern. 
Table 6. PLS-MGA (Difference in Gender)

\begin{tabular}{cccccc}
\hline Description & $\begin{array}{c}\text { Path } \\
\text { coefficients } \\
\text { (Male) }\end{array}$ & p-values & $\begin{array}{c}\text { Path } \\
\text { coefficients } \\
\text { (Female) }\end{array}$ & p-values & Remarks \\
\hline $\begin{array}{l}\text { Personal attitude -> } \\
\text { Repayment pattern }\end{array}$ & 0.262 & $0.020^{* * *}$ & 0.419 & $0.000^{* * * *}$ & $\begin{array}{c}\text { Difference } \\
\text { exist }\end{array}$ \\
$\begin{array}{l}\text { Spending pattern-> } \\
\text { Repayment pattern }\end{array}$ & 0.567 & $0.000^{* * *}$ & 0.576 & $0.000^{* * *}$ & $\begin{array}{c}\text { Difference } \\
\text { exist }\end{array}$ \\
\hline
\end{tabular}

Note. all p-values are two-tailed, * significant at $0.05, * * *$ significant at 0.001 .

This study also analyzed the categorical variable of parenthood as a multigroup analysis. Table 7 shows that the results differed significantly across the parenthood groups at 0.05 significant levels under personal attitude and spending pattern.

Table 7. PLS-MGA (Difference in Parenthood)

\begin{tabular}{cccccc}
\hline Description & $\begin{array}{c}\text { Path coefficients } \\
\text { (With children) }\end{array}$ & p-values & $\begin{array}{c}\text { Path } \\
\text { coefficients } \\
\text { (Without } \\
\text { children) }\end{array}$ & p-values & Remarks \\
\hline $\begin{array}{l}\text { Personal Attitude -> } \\
\text { Repayment pattern }\end{array}$ & 0.363 & $0.000^{* * *}$ & 0.297 & $0.000^{* * *}$ & $\begin{array}{c}\text { Difference } \\
\text { exist }\end{array}$ \\
$\begin{array}{l}\text { Spending Pattern -> } \\
\text { Repayment pattern }\end{array}$ & 0.577 & $0.000^{* * *}$ & 0.575 & $0.000^{* * *}$ & $\begin{array}{c}\text { Difference } \\
\text { exist }\end{array}$ \\
\hline
\end{tabular}

Note. all p-values are two-tailed, $*$ significant at $0.05, * * *$ significant at 0.001 .

\section{Discussion}

The results of this study revealed that all the independent variables had a direct relationship with the dependent variable. The findings revealed that personal attitude and spending pattern were important attributes in determining repayment pattern among academicians. This result is consistent with studies by Lachance (2012) which showed a positive relationship between attitude toward credit to education, the number of credit cards owned and knowledge of credit. Kidwell and Turrisi (2000) and Hayhoe et al. (2000) found that cognitive variable and affective credit attitude influenced the acquiring of credit cards and credit card usage. 
On the other hand, the influence of spending pattern on the credit card repayment pattern of academicians was supported by Chatterjee and Rose (2011) as low self-regulatory capabilities end up with credit card misuse and indebtedness. People are willing to spend more when they are using credit cards, contributing to compulsive spending along with shorter decision-making time for item purchase (Feinberg, 1986; Shimp \& Moody, 2000; Soman, 2001; Awanis \& Chi Cui, 2014). Lastly, gender and parenthood differed among academicians at Universiti Tunku Abdul Rahman in terms of their repayment of credit cards. The findings indicated that male and female academicians revealed different credit card repayment patterns. Furthermore, academicians with children had a different personal attitude and spending pattern in their credit card repayment behavior compared to those without children.

\section{Conclusion}

In conclusion, educators could play their part by giving advice and being role models to coach the younger generation to adopt a positive attitude and to sharpen their decision-making ability in particular concerning financial matters in this highly globalized society. The present study has two limitations. Firstly, the sample of this study was relatively small and only focused on a private university. For future research, a nationwide study could be considered to secure a wider range of respondents from both private and public higher learning institutions.

Secondly, only two variables were included in this study, which could indicate that the findings may not be generalizable. Future researchers could focus on other general attributes of credit card payment among academicians, for instance, attitude towards credit card debts and payment methods, inducement factors for acquiring and choice of credit cards. This study provides favorable implications to a number of interest groups on repayment studies. Stakeholders would be interested to understand the personal attitude, spending pattern and repayment pattern of academicians. The outcome would assist cardholders to fathom the importance of their attitude towards managing money, credit and debt which could eventually contribute towards a healthier credit card repayment pattern.

In addition, the above findings could provide some implications to banks and credit card companies. For instance, banks could publish or share relevant information to the public pertaining to the importance of credit card repayment and the consequences for failing to do so.

In terms of the big picture, the findings from this study would enable the government to understand the correlation between credit card repayment and bankruptcy rates among credit card holders. Campaigns could be conducted by the government to educate young consumers on the usage of credit cards 
including tightening of regulations for new credit card applicants. Outcome of this study would also enable credit card companies to review the requirements of issuing credit cards in contributing towards a financially healthier society.

In light of the results, this study is also expected to positively reach out to the younger generation through the academicians. Peer effect plays an important role in lowering repayment defaults (Breza, 2012) and this study has evidenced that peers' repayment behavior influences one's repayment behavior significantly. Therefore, educators and, academicians alike are encouraged to portray a clean and financial-distress-free image to the young and to foster positive peer-to-peer influences as the way forward to an informed society of low poverty.

\section{References}

Ahmed, Z. U., Ismail, I., Sohail, M. S., Tabsh, I., \& Alias, H. (2010). Malaysia consumers' credit card usage behavior. Asia Pacific Journal of Marketing and Logistics, 22(4), 528-544.

Ajzen, I. (1991). The theory of planned behavior. Organizational Behavior and Human Decision Processes, 50(3), 179-211.

Ajzen, I. (2006). Constructing a TPB questionnaire: Conceptual and methodological considerations. Retrieved from http://www-unix.oit. umass.edu/\%7Eaizen/

Amin, H. (2012). Patronage factors of Malaysian local customers toward Islamic credit cards. Management Research Review, 35(6), 512-530.

Amin, H. (2013). Factors influencing Malaysian bank customers to choose Islamic credit cards: Empirical evidence from the TRA model. Journal of Islamic Marketing, 4(3), 245-263.

Ausubel, L. M. (1997). Credit card defaults, credit card profits, and bankruptcy. Am. Banker. LJ, 71, 249.

Awanis, S., \& Chi Cui, C. (2014). Consumer susceptibility to credit card misuse and indebtedness. Asia Pacific Journal of Marketing and Logistics, 26(3), 408-429.

Bank Negara Malaysia. (2016). BNM Catalogue - Monthly Statistical Bulletin June 2016. Retrieved from http://www.bnm.gov.my/ index.php?ch=en_publication_catalogue\&pg=en_publication_ $\mathrm{msb} \& \mathrm{mth}=6 \& \mathrm{yr}=2016 \&$ lang $=\mathrm{en}$.

Bank Negara Malaysia. (2016). BNM Payment Systems - List of Regulatees. Retrieved from http://www.bnm.gov.my/?ch=ps\&pg=ps regulatees\#Credit.

Bernama. (2017, October 10). Maybank eyes RM2bil growth in card billings market share. Retrieved from https:/www.thestar.com.my/business/businessnews/2017/10/10/maybank-eyes-rm2bil-growth-in-card-billings-marketshare/. 
Bertaut, C. C., \& Haliassos, M. (2001). Debt revolvers for self control. Discussion paper.

Bertaut, C. C., Haliassos, M., \& Reiter, M. (2009). Credit card debt puzzles and debt revolvers for self control. Review of Finance, 13(4), 657-692.

Bresiger, G. (2018). The Fed could trigger a personal debt crisis. New York Post: Retrieved from https://nypost.com/2018/02/03/the-fed-could-trigger-apersonal-debt-crisis/.

Breza, E. (2012). Peer effects and loan repayment: Evidence from the Krishna default crisis. Job Market Paper MIT, 1.

Brown, S., Taylor, K., \& Price, S. W. (2005). Debt and distress: Evaluating the psychological cost of credit. Journal of Economic Psychology, 26(5), 642-663.

Cankaya, S., Ucal, M., \& O’Neil, M. L. (2011). Effects of gender on credit card usage among university students in Turkey. African Journal of Business Management, 5(22), 9023-9030.

Cebeci, I., \& Sanli, T. (2016). A research study on the attitude towards credit card usage of the academic staff at Giresun University in Turkey. Global Journal for Research Analysis, 5(4), 117-119.

Chan, R. (1997). Demographic and attitudinal differences between active and inactive credit cardholders - the case of Hong Kong. International Journal of Bank Marketing, 15(4), 117-25.

Chatterjee, P., \& Rose, R. L. (2011). Do payment mechanisms change the way consumers perceive products? Journal of Consumer Research, 38(6), 1129-1139.

Chien, Y. W., \& Devaney, S. A. (2001). The effects of credit attitude and socioeconomic factors on credit card and installment debt. Journal of Consumer Affairs, 35(1), 162-179.

Chin, W. W., Gopal, A., \& Salisbury, W. D. (1997). Advancing the theory of adaptive structuration: The development of a scale to measure faithfulness of appropriation. Information Systems Research, 8(4), 342-367.

Chong, F. N. (2017). Factors affecting credit card debt payment in Malaysia. International Journal of Business and Economics, 16(1), 21.

Chudry, F., Foxall, G., \& Pallister, J. (2011). Exploring attitudes and predicting intentions: Profiling student debtors using an extended theory of planned behavior. Journal of Applied Social Psychology, 41, 119-149. Doi:10.1111/j.1559-1816.2010.00705.x

Dewri, L. V., Islam, M.R., \& Saha, N.K. (2016). Behavioral analysis of credit card users in a developing country: A case of Bangladesh. International Journal of Business and Management, 11(4), 299.

Elangkovan, K., \& Ahmed, R. A. L. (2013). Bankruptcy: A natural phenomena being attacked on Malaysians. International Journal of Humanities and Management Sciences, 1(1), 74-76. 
Feinberg, R. A. (1986). Credit cards as spending facilitating stimuli: A conditioning interpretation. Journal of Consumer Research, 13(3), 348356.

Fornell, C., \& Larker, D. F. (1981). Evaluating structural equation models with unobservable variables and measurement error. Journal of Marketing Research, 39-50.

Furnham, A., \& Boo, H. C. (2011). A literature review of the anchoring effect. The Journal of Socio-Economics, 40(1), 35-42.

Godwin, D. D. (1998). Household debt quintiles: Explaining changes 19831989. Journal of Consumer Affairs, 32(2), 369-393.

Hair, J. F., Black, W. C., Babin, B. J., \& Anderson, R. R. (2010). Multivariate data analysis. Prentice- Hall, Upper Saddle River, NJ.

Hamilton, R., \& Khan, M. (2001). Revolving credit card holders: Who are they and how can they be identified? Service Industries Journal, 21(3), 3748.

Hayhoe, C. R., Leach, L. J., Turner, P. R., Bruin, M. J., \& Lawrence, F. C. (2000). Differences in spending habits and credit use of college students. Journal of Consumer Affairs, 34(1), 113-133.

Huebner, J., Fuchs, K., \& Ilic, A. (2018). Preventing over-spending: Increasing salience of credit card payments through smartphone interventions. Multikonferenz Wirtschaftsinformatik. Data driven X-Turning Data into Value, 4.

Hussin, S. R., Kassim, S., \& Jamal, N. (2013). Credit card holders in Malaysia: Customer characteristics and credit card usage. International Journal of Economics and Management, 7(1), 108-122.

Jusoh, Z., \& Lin, Y. L. (2012). Personal financial knowledge and attitude towards credit card practices among working adults in Malaysia. International Journal of Business and Social Science, 3(7),176-185.

Kaynak, E., \& Harcar, T. (2001). Consumers' attitudes and intentions towards credit card usage in an advanced developing country. Journal of Financial Services Marketing, 6(1), 24-39.

Kennedy, B. \& Wated, G. (2011). Predicting credit card debt among college students: The attitude-behavior relation. Journal of Psychology \& Behavioral Sciences, 22, 43-50.

Kidwell, B., \& Turrisi, R. (2000). A Cognitive Analysis of Credit Card Acquisition and College Student Financial Development. Journal of College Student Development, 41(6), 589-98.

Kim, H., \& DeVaney, S. A. (2001). The determinants of outstanding balances among credit card revolvers. Journal of Financial Counseling and Planning, 12(1), 67.

Kinsey, J. (1981). Determinants of credit card accounts: An application of Tobit analysis. Journal of Consumer Research, 8(9), 172-182. 
Kish, A. (2006). Perspectives on recent trends in consumer debt. Federal Reserve Bank of Philadelphia, Philadelphia.

Klein, L. (1999). It's in the cards: Consumer credit and the American experience. Greenwood Publishing Group.

Krejcie, R. V., \& Morgan, D. W. (1970). Determining sample size for research activities. Educ psychol meas.

Lachance, M. J. (2012). Young adults' attitudes towards credit. International Journal of Consumer Studies, 36(5), 539-548.

Leow, M., \& Crook, J. (2014). Intensity models and transition probabilities for credit card loan delinquencies. European Journal of Operational Research, 236(2), 685-694.

Limbu, Y. B., Huhmann, B. A., \& Xu, B. (2012). Are college students at greater risk of credit card abuse? Age, gender, materialism and parental influence on consumer response to credit cards. Journal of Financial Services Marketing 17(2),148-162.

Livingstone, S. M., \& Lunt, P. K. (1992). Predicting personal debt and debt repayment: Psychological, social and economic determinants. Journal of Economic Psychology, 13(1), 111-134.

Lydia, N. (2017). Credit card spending on the rise. The Malaysian Reserve. Retrieved from https://themalaysianreserve.com/2017/07/17/credit-cardspending-rise.

McHugh, S., \& Ranyard, R. (2012). Credit repayment decisions: The role of long-term consequence information, economic and psychological factors. Review of Behavioural Finance, 4(2), 98-112.

Mottola, G. R. (2013). In our best interest: Women, financial literacy, and credit card behavior. Numeracy, 6(2), 4.

Navarro-Martinez, D., Salisbury, L. C., Lemon, K. N., Stewart, N., Matthews, W. J., \& Harris, A. J. (2011). Minimum required payment and supplemental information disclosure effects on consumer debt repayment decisions. Journal of Marketing Research, 48(SPL), S60-S77.

Nga, J. K. H., Yong, L. H. L., \& Sellappan, R. (2011). The influence of image consciousness, materialism and compulsive spending on credit card use intentions among youth. Young Consumers, 12(3), 243-53.

Nurul Hudani, M. N., Marof, R. \& Noor Hisham, M. N. (2013). The effects of relationship management, self-management and social awareness sub-scales on transformational leadership behaviour among educational leaders. Akademika, 83(2\&3), 3-11.

Omar, N. A., Rahim, R. A., Wel, C. A. C., \& Alam, S. S. (2014). Compulsive buying and credit card misuse among credit card holders: The roles of selfesteem, materialism, impulsive buying and budget constraint. Intangible Capital, 10(1), 52-74. 
Prelec, D., \& Simester, D. (2001). Always leave home without it: A further investigation of the credit-card effect on willingness to pay. Marketing Letters, 12(1), 5-12.

Raghubir, P., \& Srivastava, J. (2008). Monopoly money: The effect of payment coupling and form on spending behavior. Journal of Experimental Psychology: Applied, 14(3), 213.

Ramayah, T., Nasser, N., Aizzat, M., \& Lim, H. C. (2002). Cardholders' attitude and bank credit card usage in Malaysia: An exploratory study. Asian Academy of Management Journal, 7(1), 75-102.

Rasiah, D., \& Masuod, S. (2013). The flexible alternative consumer financing in Malaysia, credit cards. Journal of Social and Development Sciences, 4(3), 147-151.

Roberts, J.A., \& Jones, E. (2001). Money attitudes, credit card use, and compulsive buying among American college students. Journal of Consumer Affairs, 35(2), 213-240.

Sekaran, U., \& Bougie, R. (2009). Research methods for business (5th ed.) John Wiley \& Sons Ltd.

Shimp, T. A., \& Moody, M. P. (2000). In search of a theoretical explanation for the credit card effect. Journal of Business Research, 48(1), 17-23.

Silva, J., \& Draut, T. (2004). Generation broke: The growth of debt among young Americans. New York: Demos: Borrowing to make ends meet briefing paper, 2.

Soll, J. B., Keeney, R. L., \& Larrick, R. P. (2013). Consumer misunderstanding of credit card use, payments, and debt: Causes and solutions. Journal of Public Policy \& Marketing, 32(1), 66-81.

Soman, D. (2001). Effects of payment mechanism on spending behavior: The role of rehearsal and immediacy of payments. Journal of Consumer Research, 27(4), 460-474.

Soman, D., \& Cheema, A. (2002). The effect of credit on spending decisions: The role of the credit limit and credibility. Marketing Science, 21(1), 3253.

Sprenger, C., \& Stavins, J. (2008). Credit card debt and payment use. Federal Reserve Bank of Boston Working Paper No. 08-2.

Stavins, J. (2000). Credit card borrowing, delinquency, and personal bankruptcy. New England Economic Review, 15.

Stewart, N. (2009). The cost of anchoring on credit-card minimum repayments. Psychological Science, 20(1), 39-41.

Surane, J. (2017), U.S. credit-card debt surpasses record set at brink of crisis, Bloomberg. Retrieved from https:/www.bloomberg.com/news/ articles/2017-08-07/u-s-credit-card-debt-surpasses-record-set-at-brinkof-crisis.

Tan, A. K., Ten, S. T., \& Loke, T. J. (2011). Credit card holders, convenience users and revolvers: A tobit model with binary selection and ordinal treatment. Journal of Applied Economics, 14(2), 225-255. 
Tasnim, L. (2017, August 21). 3.6 million credit card holders have RM36.9 billion outstanding balance. New Straits Times. Retrieved from https:// www.nst.com.my/news/nation/2017/08/270620/36-million-credit-cardholders-have-rm369-billion-outstanding-balance

Themba, G., \& Tumedi, C. B. (2012). Credit card ownership and usage behavior in Botswana. International Journal of Business Administration, 3(6), 60-71.

Theory of Planned Behavior. (1991). Value Based Management. Retrieved from http://www.valuebasedmanagement.net/methods_ajzen_theory_ planned_behavior.html.

Wang, L., Lu, W., \& Malhotra, N. K. (2011). Demographics, attitude, personality and credit card features correlate with credit card debt: A view from China. Journal of Economic Psychology, 32(1), 179-193.

Webley, P., \& Nyhus, E. K. (2001). Life-cycle and dispositional routes into problem debt. British Journal of Psychology, 92(3), 423-446.

Wong, K. Y., \& Lynn, M. (2017). The easy-money effect: Credit card spending and hard-work reminders. Journal of Consumer Marketing, 34(7), 541551.

Yoo, P. S. (1998). Still charging: The growth of credit card debt between 1992 and 1995. Federal Reserve Bank of St. Louis Review, (1), 19-27.

Zhao, Y., Zhao, Y., \& Song, I. (2009). Predicting new customers' risk type in the credit card market. Journal of Marketing Research, 46(4), 506-517. 